\title{
Transmisja i reprodukcja wartości kulturowych w szkole na przykładzie wybranych mniejszości narodowych i etnicznych a kontekst społeczny. Elementy założeń teorii Pierre'a Bourdieu i Basila Bernsteina
}

Streszczenie: Rodzina i szkoła nie zawsze stanowią kompatybilne środowiska wychowawcze, zwłaszcza w sytuacji różnic kulturowych, wynikających z przynależności do odmiennych narodowo i etnicznie grup. Istnieje potrzeba wielodyscyplinarnych analiz dotyczących transmisji i reprodukcji wartości kulturowych i roli szkoły w uwzględnianiu owych różnic w praktyce szkolnej.

Przed szkołą pojawiają się szczególne zadania o charakterze regulacyjnym, aksjologicznym, adaptacyjnym, służącym jednocześnie integracji środowisk kulturowo odmiennych ale uwzględniających także potencjał kulturowy grup mniejszościowych. W prezentowanym artykule odmienność habitusów trzech wybranych mniejszości i grup etnicznych (Wietnamczycy, Czeczeni i Romowie w polskiej szkole) została poprzedzona teoretycznymi rozważaniami z wykorzystaniem elementów teorii Pierre’a Bourdieu i Basila Bernsteina. W każdej z nich podkreśla się kwestie związane ze stratyfikacją społeczną, która z uwagi na różnice w habitusach, poziomach sprawności lingwistycznej i „przemocy” symbolicznej kultury grupy większościowej stawia pod znakiem zapytania szanse edukacyjne i integrację społeczną mniejszości w przestrzeni szkoły. Obok przykładów dobrej integracji społecznej (uczniowie wietnamscy) szkoła jest miejscem barier interakcyjnych (uczniowie czeczeńscy) oraz przestrzenią, w której dokonuje się świadomy wybór izolacji w celu ochrony własnej tożsamości (Romowie).

Słowa kluczowe: transmisja, reprodukcja, szkoła, mniejszości, grupy etniczne

\section{Wprowadzenie}

Rodzina i szkoła stanowią podstawowe i najbliższe zarazem dziecku środowiska wychowawcze. Proces socjalizacji odbywa się najpierw w rodzinie, gdzie zgodnie z przyjętą $\mathrm{w}$ niej hierarchią wartości następuje poznawanie 
świata i wyposażenie dziecka w instrumenty owego poznania. Uporządkowanie wartości i ich struktura obowiązująca w rodzinie wyznacza wybory idei, przyjęcie myśli, postaw oraz sposoby przeżywania świata i jego doświadczania (Denek,1994). Kształtują one zręby osobowości, która na dalszym etapie socjalizacji - w zinstytucjonalizowanych formach edukacji szkolnej - jest dalej rozwijana i poddawana konfrontacji z posiadanym już „wyposażeniem” w system wiedzy, emocji, wartości, idei i duchowości, których praźródłem jest rodzina. W niej następuje interioryzacja tego co niematerialne, włączenie w system myśli i sądów wzorców kulturowych i norm społecznych, wyznaczających kierunki wyboru dróg życiowych, jakość interakcji społecznych i preferencje. Obowiązujący zaś w rodzinie kod językowy, w zależności od jej statusu społecznego określa poziom definiowania i kategoryzowania świata, co w kolejnych etapach socjalizacji i szkolnej edukacji sytuuje dziecko w określonej grupie na zasadach stratyfikacji społecznej.

\section{Rodzina i szkoła w teoretycznych założeniach Pierre’a Bo- urdieu i Basila Bernsteina}

Transmisja wartości w rodzinie zależy w dużej mierze od jakości relacji, obowiązujących w niej ról, przekazu międzypokoleniowego i kształtowanego w niej habitusu. Bourdieu i Jean-Claude Passeron definiują go jako „kompleks interioryzacji, czyli tendencji, postaw, dyspozycji uwewnętrznionych, wprowadzonych w sferę ludzkich nawyków. Habitus rozciąga się na dziedzinę ocen, emocjonalnych reakcji, stosunku do wartości. Jest on właśnie rezultatem subiektywizacji obiektywności wyrażającym się z kolei znów w sposób obiektywny" (Bourdieu, Passeron, 2006, s. 13-14). Habitus staje się wyznacznikiem społecznego funkcjonowania dziecka w kolejnych etapach życia, a zatem egzystencji w pojawiających się kolejno grupach społecznych i pełnionych w nich rolach oraz instytucjach edukacyjnych, jakimi są szkoły. Wyodrębniony przez Bourdieu i Passerona całokształt dyspozycji wyznaczający społeczne funkcjonowanie człowieka opiera się o jakość przekazów i poziom kultury językowej, warunkujących dystrybucję kultury i określony typ kapitału społecznego.

Zgodnie z koncepcją autorstwa Bernsteina, oparty na nierównościach społecznych system edukacji tworzy mechanizmy dystrybucji władzy narzucanej przez grupę dominującą, dysponującą kodem językowym, w którym odbywa się transmisja wiedzy i znaczeń. U Bernsteina grupą tą jest klasa średnia, a zatem szkoła tworzy strukturę wiedzy, znaczeń najpełniej zinterna- 
lizowaną przez uczniów pochodzących ze średniej klasy społecznej. Stanowi to kryterium wykluczenia w przypadku uczniów reprezentujących niższy status społeczny, a ma to miejsce w zróżnicowanej narodowościowo i etnicznie klasie szkolnej. Transmisja wartości kulturowych odbywa się na podstawie uprawomocnionej kulturowo reprodukcji znaczeń, odpowiadających ogólnie przyjętym przez szkołę kodom kulturowym, które z racji obwiązującej sprawności lingwistycznej są dla reprezentantów innych kultur narodowych i etnicznych jawną przemocą symboliczną. Jak pisze Tomasz Gmerek (2014, s. 169) język dominującej grupy etnicznej jest elementem narzucania określonych dyskursów (uznanych za prawomocne i jedynie właściwe) podporządkowanym grupom etnicznym.

Szkoła stanowi kolejny etap na drodze socjalizacji, poszerzający znacznie wachlarz oferowanych wartości, nie zawsze jednak kompatybilnych w stosunku do tych, których źródło stanowi rodzina. Habitus, a także kody edukacyjne wyrażane za pośrednictwem języka narzucane przez szkołę w pewnych okolicznościach i warunkach edukacyjnych stwarzają konieczność nowej interpretacji świata, niezgodnej z całością dotychczasowych doświadczeń, stylu życia i podzielanych wartości, których umocowanie tkwi w rodzinie. Owa niezgodność ma miejsce z całą wyrazistością w konflikcie habitusów i różnych poziomach sprawności lingwistycznej w edukacji szkolnej dziecka reprezentującego inne kultury narodowe czy etniczne w polskiej szkole. Przebiegające $\mathrm{w}$ rodzinie procesy socjalizacyjne w przypadku różnic kulturowych i „zderzeń” etnosów, o których pisze Jerzy Nikitorowicz (2009), na płaszczyźnie szkoły mogą powodować daleko idące konsekwencje natury kulturowej, jak i społeczno-psychologicznej jednostki. Ich implikacją może być dokonujący się w czasie proces formowania tożsamości. Tzw. ukryte programy szkolne, pod którymi dokonuje się niezdolność, a może brak dobrej woli, w organizacji wzajemnej transmisji kulturowej i wprowadzania w nowe role społeczne uczniów, pogłębiają często tzw. przemoc symboliczną. Przejawia się ona w narzucaniu wzorców kulturowych i ich interpretacji (można to określić za Bourdieu przemocą symboliczną), z pominięciem „własnych” habitusów szkolnych podmiotów, będących konsekwencją wychowania w rodzinie. Dotyczy to także językowych uwarunkowań szkolnych niepowodzeń, które - jak podkreśla Joanna Bielecka-Prus (2010) - u B. Bernsteina wynikały z relacji między podstawowymi instytucjami socjalizującymi - rodziną i szkołą. Znaczne rozbieżności między transmisją i reprodukcją kulturową w rodzinie i szkole, zwłaszcza w wielokulturowym środowisku szkoły, wzmacniają mechanizmy nierówności edukacyjnych i wykluczenia grup 
mniejszościowych. Kwestia ta jest szczególnie wrażliwa w przypadku wielokulturowej przestrzeni szkoły i różnorodności jej etnosów. Różnice w posiadanym kapitale społeczno-kulturowym zawsze stanowić będą czynnik różnicujący szanse edukacyjne. Niższe kompetencje komunikacyjne i słabszy poziom sprawności lingwistycznej utrudniają transmisję znaczeń i kulturowych kodów w szkole. Wyznaczane wzorcami kulturowymi poszczególnych społeczności etos i hierarchia wartości, z różnym w niej uplasowaniem edukacji, pozwala sądzić, że transmisja wartości kulturowych w rodzinie zawsze stanowić będzie odrębną płaszczyznę społecznych interakcji od tego samego procesu w warunkach szkoły. I odbywać się to będzie nie tylko z racji różnic kulturowych, ale nawet różnic w posiadanym kapitale społeczno-kulturowym w obrębie tej samej grupy narodowościowej czy etnicznej. Bourdieu uważa, że wpajanie kultury symbolicznej w świadomość społeczną jest zależne od przynależności społecznej, czy klasowej. Powoduje to nierówny dostęp do dóbr symbolicznych (takich jak wykształcenie, reputacja, „układy” itd.) i - w opinii Jerzego Szackiego (2002) - nadaje punktowi widzenia Bourdieu charakter klasowy. Jednak kategoria klasowości nie wydaje się w ujęciu Szackiego najważniejszą w socjologii Bourdieu. Stosuje on też pojęcie pola, stanowiącego swego rodzaju przestrzeń społeczną, którą może być również oświata i nauka. Wielowymiarowość i dynamiczny charakter każdego z pól społecznych tworzy liczne konfiguracje. W każdym z tych pól toczy się gra o zawłaszczenie możliwie dużego „kapitału”, tworzą się struktury społeczne, które „określają granice wolności i szanse sukcesu uczestników gry, w której stawką jest dominacja i monopolizacja danego rodzaju kapitału, uzyskanie możliwości stosowania prawomocnej przemocy symbolicznej nad słabszymi, stanowienia norm obowiązujących na danym polu" (Szacki, 2002, s. 900).

\section{Kapitał kulturowy szkoły - grupy dominujące a mniejszości}

Szkoła stanowi niewątpliwie jedno z pól w socjologii przestrzeni społecznych Bourdieu. W trawestacji do jego poglądów w wielokulturowej szkole można mówić o dominacji i monopolizacji kapitału kulturowego, jaki wnosi grupa większościowa w stosunku do nielicznie reprezentowanych całkowicie odmiennych habitusów, przez przedstawicieli mniejszości narodowych i etnicznych stanowiących podmioty szkolne w polskich placówkach edukacyjnych. Czy o ich pozycji społecznej w większościowej strukturze uczniów narodowości polskiej, z racji niższej liczebności przesądza odmienny kapitał kultu- 
rowy? Co warunkuje szanse edukacyjne uczniów reprezentujących odmienne kultury narodowe i etniczne? Czy podlegają oni procesowi „przemocy” symbolicznej z racji narzucania wzorców kulturowych grupy większościowej? Jak przebiega transmisja wartości kulturowych w rodzinach uczniów kulturowo "odmiennych" i czy wpływa ona na transmisję wartości w polskiej szkole? Co decyduje o stanowieniu norm społecznych w klasie szkolnej zróżnicowanej narodowo i etnicznie? Pojawiające się pytania i wątpliwości inspirują do poszukiwań zarówno na płaszczyźnie teoretycznej, jak i empirycznej. Są również konsekwencją moich osobistych poszukiwań i badawczych eksploracji w szkole na przykładzie uczniów romskich, wietnamskich i czeczeńskich.

Tomasz Szkudlarek (2010) podnosi kwestię tzw. ukrytych programów szkolnych, obejmujących niewidoczne w realnym funkcjonowaniu szkoły wartości, idee czy zamierzenia. Zauważa on wspomnianą już „symboliczną przemoc”, skłaniającą do reprodukcji kulturowej w szkole, „upośledzającą” wartości innych kultur niż dominująca.

Szkoła nie jest instytucją, która może wyrównać różnice w „społecznie ustanowionej naturze" (Bourdieu, Passeron, 2006, s. 15), wynikającej z przynależności do określonej mniejszości narodowej czy etnicznej, a nawet nie powinna o to zabiegać. Różnorodność kulturowa podmiotów edukacyjnych stanowi o bogactwie habitusów a tym samym kreuje nowe pola „ścierania się" i wzajemnych społeczno-kulturowych konfrontacji. Z żadnej strony nie powinna mieć miejsca „symboliczna przemoc”, będąca formami narzucania dominującej kultury i tworzenia szkolnego habitusu, w którym mniejszość ulega szkolnej dominacji i kulturowej supremacji większości. Jednak Bielecka-Prus (2010), powołując się na stanowiska N. Stehra i J. Heymanna, podziela wraz z nimi pogląd, że w systemie edukacji ukryty jest pewien paradoks: $\mathrm{z}$ jednej strony - we współczesnych społeczeństwach wykształcenie jest podstawowym czynnikiem mobilności społecznej, a z drugiej - instytucje edukacyjne mogą tę mobilność znacznie hamować. Przywołuje ona pogląd Williama L. Warnera, zdaniem którego „edukacja jest jak taśma produkcyjna, która najwcześniej wysadza tych, którzy są z warstw niższych, a ci z wyższych dochodzą do jej końca" (Bielecka-Prus, 2010, s. 80).

Rozróżniając transmisję wartości kulturowych w rodzinie i w szkole w odniesieniu do kultur narodowych i etnicznych, należy też podkreślić - odnosząc się do założeń socjologicznych Bourdieu - że, najważniejszym miejscem inicjalnego etapu pracy pedagogicznej stanowiącej absolutny początek wpajania kultury jest rodzina. „Ten proces dokonuje się w rodzinie w małych grupach pierwotnych i w lokalnym środowisku pochodzenia" - konkluduje Bo- 
urdieu i uznaje, że habitus tworzący się w tej najbliższej dziecku przestrzeni, stanowi podstawę wszystkich późniejszych faz w pracy pedagogicznej, a więc i formach instytucjonalnych (Bielecka-Prus, 2010, s. 29). Zatem pierwotny, podstawowy habitus stanowi podstawę przyswajania kolejnych habitusów, jakie kształtuje np. szkoła.

Pierwotna socjalizacja opierająca się o wpajanie wartości w najbliższym dziecku środowisku wychowawczym poddawana zostaje w jego rozwoju ontogenetycznym i społeczno-kulturowym nowym systemom wartości, nie zawsze kompatybilnym. Dotyczy to zwłaszcza szkoły, jako środowiska wychowawczego dla uczniów pochodzących z innych niż polskie kultur narodowych, czy etnicznych. Powstaje wówczas pytanie: w jakich formach i o jakim natężeniu spotykają się oni z przemocą symboliczną w polskiej szkole? Czy wpajana kultura większości napotyka opór pierwotnego habitusu? Czy posiadany kapitał lingwistyczny, inny od grupy większościowej, może wspomagać rozwój społeczny z pozycji mniejszości w mechanizmach stratyfikacji społecznej grupy większościowej? Czy świadomość mniejszości i odmiennych habitusów utrudnia szkolną edukację czy też stanowi czynnik konstytuowania się odrębności i zmierzania w stronę własnych korzeni kulturowych?

Zdaniem Bourdieu, przemoc symboliczna może być wzmagana przez powtarzające się formy wpajania elementów kultury innej od pierwotnego habitusu, „ale ze względu na silny wpływ determinujący, mogący (...) zamykać w jednym kręgu kultury, utrudniać przemiany na kolejnych progach kształcenia, więzić w obrębie wartości, które $\mathrm{z}$ różnych względów nie muszą zawsze być oceniane jako najlepsze" (Bielecka-Prus, 2010, s. 30-31). Powstaje więc kolejna wątpliwość: czy w polskiej szkole dziecko kulturowo „obce” nie jest poddawane - z naturalnej konieczności systemu edukacyjnego i jego teleologii - aksjologicznej lokacji w obcej mu przestrzeni społeczno-kulturowej? Gdzie przebiega granica wzajemnej tolerancji i jakie alternatywy w edukacji chronią przed symboliczną przemocą? Czy jest to w ogóle możliwe?

\section{Habitusy pierwotne badanych grup ,innych” kulturowo a habitus polskiej szkoły - refleksje i wnioski z badań}

Badania, które przeprowadziłam w trzech różnych szkołach (trzy różne województwa) wynikały z przyjętej przeze mnie perspektywy metodologicznej. Celem była diagnoza percepcji „obcych” narodowościowo i etnicznie uczniów w wybranych szkołach i określenie społecznej przestrzeni wielokulturowej szkoły. Z uwagi na obecność Romów, Czeczenów i Wietnamczyków, 
wybrano trzy różne placówki, w których każda z tych grup stanowiła większość „obcych” narodowo i etnicznie uczniów, stanowiących jednak w stosunku do uczniów polskich zdecydowaną mniejszość. Każdą z tych szkół cechował inny charakter wzajemnych relacji, wynikających z odmiennych habitusów i sprawności językowej „obcych”. Łącznie badaniami objęto 374 uczniów narodowości polskiej, z czego 192 w klasach z obecnością rówieśników czeczeńskich, 71 - w klasach z obecnością uczniów wietnamskich i 111 - w klasach szkoły, gdzie uczęszczali uczniowie romscy. Liczba uczniów obcych w badanych szkołach była zróżnicowana, zależna od czynników lokalnych i administracyjnych. Badania mają charakter studium monograficznego. Wpisują się bowiem w trzy odmienne przestrzenie edukacyjne. Zastosowane metody i techniki badawcze (dane empiryczne poddano analizie ilościowej i jakościowej) zostały określone we wcześniejszej publikacji (Dobrowolska, 2015, s. 44).

W każdej z wymienionych grup, reprezentujących inne kultury narodowe i etniczne, habitusy pierwotne określone są licznymi teoretycznymi studiami wraz z wynikami badań z zakresu socjologii i antropologii kulturowej. Odnoszą się jednak bardziej do cech wspólnych dla danej kultury narodowej i etnicznej, niż do zdeterminowanej społecznie grupy, czy klasy społecznej w obrębie określonej narodowości (chodzi o Czeczenów, Wietnamczyków i Romów). Są one zatem uznane za przyjęty społecznie i wyznaczony społeczną naturą każdej z grup habitus. Przynależna wymienionym grupom sfera kultury (w ujęciu Bourdieu wyznaczona przynależnością do klasy społecznej) jest w ocenie badacza dość uproszczona. Nie wnika bowiem w niuanse społecznych różnic wynikających z przynależności do klasy społecznej (można ją różnicować np. u Romów uwzględniając kastowość romskiej społeczności, Czeczenów i Wietnamczyków, u których klasy społeczne również różnicowane są stylem życia, dyspozycjami i praktykami społecznymi), lecz koncentruje się na typowych cechach przedstawicieli badanych społeczności. Należy też wziąć pod uwagę teren badań, jaki stanowi szkoła. Nie zawsze pozwala ona na ujawnienie się cech i dyspozycji pozostających w gestii posiadanego kapitału osobowego i kulturowego osób narodowościowo i etnicznie „innych”. W przypadku kapitału kulturowego, o którym stanowi język oraz dobra kulturowe, nie jest on w polskiej szkole wykorzystywany, poza spektakularnymi imprezami szkolnymi, będącymi promocją wybranej kultury (np. Dzień kultury czeczeńskiej, Dni kultury romskiej). Kapitał społeczny z kolei, będący - w opinii Bourdieu - zdolnością zarządzania zasobami materialnymi i symbolicznymi oraz wyrażający się w kontaktach społecznych nie zawsze 
stanowi podstawę do nawiązywania nowych więzi formalnych i nieformalnych z przedstawicielami grupy większościowej (Szlendak, 2010). Wynika to z różnic kodów kulturowych, sprawności językowej, którą Bernstein uznaje za narzędzie transmisji znaczeń i pełnienia kontroli społecznej. Język jest zatem kategorią nadającą grupie dominującej status społecznego uprzywilejowania z jednoczesną deprecjacją i obniżeniem szans edukacyjnych grup mniejszościowych lub też wyparcia własnej tożsamości (opanowanie języka większości) i rezygnacji z habitusu pierwotnego. Habitus polskiej szkoły opiera się na kodzie językowym większości, co uprawomocnia przekazywaną w niej wiedzę, jako jedynie słuszną. Odmienny dla „obcych” kapitał kulturowy polskiej szkoły oferuje wartości, często odmienne lub nieznane uczniom reprezentującym inne kultury narodowe i etniczne. Szczegółowe analizy dotyczące habitusu badanych szkół będą przedmiotem bardziej obszernego opracowania.

\section{Romowie - niechęć adaptacji i symboliczna przemoc czy świadomy wybór izolacji?}

Sytuacja uczniów romskich w polskiej szkole jest przedmiotem licznych badań i rozpraw, z których wyłania się obraz dziecka traktowanego w kategoriach społeczno-kulturowego wykluczania. Ewa Nowicka-Rusek (2011) w Raporcie końcowym z projektu badawczego Funkcjonowanie poznawcze $i$ językowe dzieci romskich uczęszczajacych do szkót specjalnych $i$ masowych - konteksty społeczne wyraźnie podkreśla obecność stereotypów kulturowych w szkołach, deprecjonujących uczniów romskich. Znacząca wartość wspólnoty jako grupy u Romów i silne tendencje do zachowania własnej odrębności kulturowej, izolują tę grupę od społeczeństwa większościowego. Wypełnianie obowiązku szkolnego nie jest tożsame z nawiązywaniem więzi rówieśniczych i pełną adaptacją do szkolnych wymogów. W ocenie wielu badanych nauczycieli dziecko romskie w polskiej szkole często cechują poważne deficyty intelektualne, które powodują nasilenie szkolnych trudności i w efekcie prowadzą do absencji i drugoroczności. Wspomniana autorka wskazuje na dominujący charakter kultury większościowej, co nie dopuszcza w szkolnych realiach tolerowania odstępstw i prowadzi do konfliktu wartości. Deficyty intelektualne u dzieci romskich wynikające z ograniczenia kompetencji językowych, inaczej traktowanej w pierwotnym habitusie wartości edukacji, są przyczyną masowych skierowań decyzją poradni psychologiczno-pedagogicznych do szkół specjalnych. Środowisko romskie uznaje ten fakt 
za przejaw dyskryminacji i pojawia się „wielka obawa przed skrzywdzeniem dziecka, a także przed jego demoralizacją i obniżeniem statusu społecznego" (Nowicka-Rusek, 2011, s. 44). Autorka wskazuje również na różnice w zachowaniu się dzieci romskich, co jest konsekwencją innych założeń wychowawczych w rodzinie. Nieśmiałość i skromność w przypadku dziewcząt, a skłonność do agresji, stanowczość i siła u chłopców stanowią cechy romskiego habitusu pierwotnego, który w szkolnych sytuacjach pozostaje w opozycji do zachowań społecznych grupy większościowej.

Inne badania wskazują na przykłady niezadowalającej sytuacji dzieci romskich w praktyce szkolnej i brak staranności ze strony nauczycieli. Uzyskane w tych badaniach relacje asystentów romskich potwierdzają dystans, a nawet wrogość, co pozwala stwierdzić istnienie ukrytego programu szkolnego (Dobrowolska, 2015, s. 173-175). Symboliczną przemocą wobec dzieci romskich można określić formy pracy z nimi, nie uwzględniające specyfiki mentalności, postaw i struktur poznawczych, wynikających z interioryzacji kodów kulturowych.

Z prowadzonych przeze mnie analiz statystycznych zebranego materiału empirycznego (badaniami objęłam uczniów z klas V i VI w liczbie 111 osób, w jednej ze szkół, do której uczęszczają dzieci romskie) a dotyczącego sytuacji w wielokulturowych klasach z obecnością dzieci romskich wynika, że :

- niska frekwencji uczniów romskich w szkole oraz znaczna liczba osób edukowanych poza szkołą (forma nauczania indywidualnego) nie sprzyja integracji społecznej. Romowie wydają się „nieobecni” w szkole i pozostają poza sferą ocen relacji uczniowskich (grupa większościowa); objęcie ich nauczaniem indywidualnym, odbywającym się poza szkołą, wyklucza ich ze społecznej przestrzeni szkoły i utrudnia procesy integracyjne;

- blisko 40\% badanych uczniów w szkole, gdzie uczą się także dzieci romskie sugeruje traktowanie Romów jako Swoich a Obcymi są tylko przybysze z innych krajów. Może to oznaczać uznanie Romów za część szkolnej społeczności;

- fakt niższych kompetencji językowych uczniów romskich, brak wsparcia w domu (niepiśmienni najczęściej rodzice), niska frekwencja szkolna i kulturowe wyznaczniki funkcjonowania społecznego Romów nie tworzą takiej samej perspektywy edukacyjnej, jak ma to miejsce w przypadku dzieci polskich. Ten wątek badań został rozpoznany na podstawie analizy jakościowej dokumentacji szkolnej, w tym dokumentacji pedagoga szkolnego i posiadanych przez szkołę decyzji wydanych przez poradnie psychologiczno-pedagogiczne. 
Potwierdzeniem takiego wniosku są dane statystyczne dotyczące frekwencji, poziomu wykształcenia Romów znajdujące się w raportach MSWiA dotyczących realizacji Programu na rzecz społeczności romskiej (Dobrowolska, 2011).

Zebrane przez mnie liczne opinie poradni psychologiczno-pedagogicznych dotyczące sytuacji szkolnej dzieci romskich potwierdzają słaby rozwój mowy i myślenia, niski poziom sprawności percepcyjno-motorycznych w tym grafomotorycznych, brak odpowiedniego przygotowania do obowiązków i zadań szkolnych. Wszystkie z tych cech stanowią domenę romskich postaw i wartości, co nie pozwala im na integrację społeczną z grupą większościową. Pierwotny habitus Romów odbiega od standardów socjalizacyjnych grupy większościowej i tym samym pogłębia wzajemne różnice kulturowe. Sytuację komplikuje innych model interakcji społecznych, a wydawane orzeczenia Poradni o nauczaniu indywidualnym z przyczyn społecznych, wydają się oddalać możliwości wzajemnego poznania i wymiany wzorów wynikających z odmiennych habitusów. Większy margines społecznej tolerancji w polskiej szkole wobec mniejszości może stworzyć bardziej przyjazną i merytorycznie dostosowaną płaszczyznę szkolnych oddziaływań. Nie bez znaczenia jest sposób traktowania Romów w środowisku lokalnym. Przykładem recepcji Romów przez instytucje lokalne i centralne jest Raport końcowy z badania ewaluacyjnego „Programu na rzecz społeczności romskiej w Polsce” realizowanego w ramach projektu „Q jakości - poprawa jakości funkcjonowania Programu Romskiego" (Pozarządowa Agencja Ewaluacji i Rozwoju, Stowarzyszenie Biuro Obsługi Inicjatyw Społecznych, 2011).

Wyjątkowa dbałość Romów i determinacja w zachowaniu własnej odrębności etnicznej jest swoistym wyborem celowej społecznej izolacji. Uczestnictwo dzieci romskich $\mathrm{w}$ polskich szkołach z graniczoną z racji kulturowych sprawnością lingwistyczną i zgoła odmiennym od większości kodem kulturowym, wydaje się wpisywać w model społecznego funkcjonowania Romów, dla których habitus pierwotny jest warunkiem tożsamości. Konstytuuje ona byt społeczności romskiej, niezależnie od ceny społecznej marginalizacji czy wykluczenia. Potencjał lingwistyczny przyjęty od grupy dominującej paradoksalnie stanowi zagrożenie dla etnicznej odrębności Romów, co uzasadnia $\mathrm{z}$ ich strony tendencję minimalizowania $\mathrm{w}$ korzystaniu $\mathrm{z}$ instytucjonalnej formy kształcenia, jaką stanowi szkoła. 


\section{Wietnamscy uczniowie - przykład dobrej integracji spo- łecznej, zbieżności habitusów i sprawności lingwistycznej w polskiej szkole}

Sytuacji szkolnej dzieci wietnamskich w polskiej szkole poświęcono już znaczną uwagę w innych opracowaniach (Halik, 2006). Odmienność środowisk wychowawczych w rodzinach wietnamskich (socjalizacja pierwotna), paradoksalnie dobrze wpływa na integrację społeczną i adaptację szkolną. Koegzystencja kultur wietnamskiej i polskiej stała się obecnie naturalnym zjawiskiem, a edukacja szkolna przyjmuje charakter procesów adaptacyjnych lub też akomodacji, jako przekształcania pierwotnego schematu myślowego (Halik, Nowicka, Połeć, 2006).

Prowadzone przez mnie badania nad tą grupą uczniów w jednej z polskich szkół potwierdzają, że:

- dzieci wietnamskie cieszą się w środowisku szkolnym sympatią, zaufaniem, uchodzą za dobrych kolegów i przyjaciół. Są dobrymi a często wzorowymi uczniami, lubianymi przez nauczycieli;

- przewaga uczniów wietnamskich (pod względem reprezentowanych kultur) i ich relacje z polskim rówieśnikami ukazują wzorcowy przykład integracji szkolnej, gdzie kulturowa odmienność nie stanowi przeszkody na drodze budowania wspólnoty, tworzenia systemów znaczeń i zachowań, wynikających z interakcji;

- Wietnamczycy wydają się być bardzo życzliwie nastawieni wobec Polaków w przeciwieństwie do dzieci reprezentujących w badanych klasach narodowość rosyjską, ormiańską czy ukraińską;

- zdaniem badanych nauczycieli równość szans edukacyjnych dzieci wietnamskich wynika z faktu dobrej znajomości języka polskiego i pełnej integracji społecznej;

- w przypadku dzieci wietnamskich w mechanizmach stratyfikacji społecznej ich wysokiej pozycji sprzyjają nastawienia i cechy osobowościowe oraz edukacja od najmłodszych lat w polskich instytucjach oświatowych (znajomość polskich kodów kulturowych i silna identyfikacja z nimi);

- równość szans edukacyjnych dzieci wietnamskich wynika w ocenie badanych z faktu dobrej znajomości języka polskiego i pełnej integracji społecznej; 
- dla uczniów wietnamskich nie istnieje bariera językowa, prowadząca najczęściej do niepowodzeń szkolnych, co czyni ich edukację w polskiej szkole nierzadko wzorową i wzorcową;

- relacje szkoły z rodzicami dzieci wietnamskich są często utrudnione $\mathrm{z}$ racji nieznajomości języka polskiego (różnice w habitusach pierwotnych i wtórnych nie implikują trudności edukacyjnych a wysoki potencjał lingwistyczny (język polski) pozwala na dobrą dystrybucję kultury i przyjęcie habitusu szkoły polskiej);

- trudność w bezpośrednich kontaktach z rodzicami dzieci „obcych” wynika najczęściej nie z faktu unikania kontaktów ze szkołą lecz nieznajomości języka polskiego, co potwierdzają sami w wywiadach uczniowie wietnamscy. Nie przeszkadza to jednak uczniom wietnamskim w przyjmowaniu „wyposażenia” kulturowego, typowego dla grupy większościowej.

Zgodnie z teorią Bourdieu, posiadany kapitał lingwistyczny określa status społeczny jednostek. W przypadku dzieci wietnamskich dobra znajomość języka polskiego decyduje o sukcesach edukacyjnych, co potwierdza się także w transmisji i reprodukcji kultury odpowiadających grupie dominującej. Można przyjąć, że dzieci wietnamskie w pełni zinternalizowały wartości kulturowe swoich polskich rówieśników, co rodzi jednak pytania o ich tożsamość narodową i transmisję wartości kulturowych w rodzinie, przy ograniczonej lub całkowitej nieznajomości języka polskiego przez rodziców.

\section{Uczniowie narodowości czeczeńskiej - niechęć do integra- cji, rozbieżność habitusów i bariery interakcyjne}

Jeszcze inną grupą, która objęłam badaniami w warunkach społeczności wielokulturowej w polskiej szkole stanowią uczniowie - imigranci z Czeczenii. Objęta badaniami szkoła znajduje się w powiatowym mieście w woj. lubelskim. Trudno jest nakreślić jednoznacznie tło kulturowe i przyczyny obecnych migracji Czeczenów do Polski z uwagi na rozległość i złożoność problemu. Faktem jest jednak obecność dzieci czeczeńskich w polskich szkołach, szczególnie w miejscach, gdzie znajdują się ośrodki dla uchodźców.

$\mathrm{Z}$ analizy danych empirycznych zdominowanych orientacją jakościową (wywiady, test niedokończonych zdań) wynika, że:

- traktowane jako marginalne problemy dzieci narodowości czeczeńskiej stanowią główne źródło trudności, wymieniane przez badanych nauczycieli; 
- warunki bytowe dzieci czeczeńskich (pobyt w ośrodku dla uchodźców), trudna sytuacja bytowa, świadomość uchodźstwa wpływają na poczucie własnej wartości, kształtują tożsamość na styku habitusu pierwotnego i szkolnego, co implikuje określone zachowania społeczne i określa poziom integracji z Obcymi, tj. Polakami;

- poczucie izolacji rodzi niechęć do pełnej i otwartej komunikacji społecznej, co upośledza proces uczenia się obcego Czeczenom języka;

- badani uczniowie polscy, podobnie jak we wcześniej uzyskanych wypowiedziach uznają Czeczenów za źródło problemów, w tym konfliktów i bójek w klasie szkolnej. Ich obecność w ocenie niektórych utrudnia uczenie się, jest przyczyną zamieszania i chaosu, spadku średniej ocen w klasie;

- znamienna w wielu wypowiedziach badanych uczniów polskich jest sugestia oddzielenia Czeczenów od uczniów narodowości polskiej, przeniesienia ich do innej, specjalnej szkoły lub klasy. Tendencja do wykluczania Czeczenów ze społeczności szkolnej nosi cechy rasizmu i całkowitego braku akceptacji;

- tylko nieliczni wykazując się empatią i zrozumieniem trudnego położenia czeczeńskich rówieśników, uznają ich prawo do szacunku, edukacji i równego traktowania;

- rodziny czeczeńskie z uwagi na inne kulturowo podstawy i wzorce wychowawcze mają do polskiej szkoły specyficzny stosunek, co przekłada się na powierzchowne relacje ze szkołą i nauczycielami;

- komunikowanie się nauczycieli z rodzicami uczniów czeczeńskich ma charakter formalny i wynika z procedur odnoszących się do kwestii związanych z uchodźstwem;

- rodzice uczniów narodowości czeczeńskiej nie znają języka polskiego, stąd komunikacja ze szkołą wymaga często pośrednika-tłumacza. Uczęszczanie dziecka do szkoły traktują raczej w kategoriach przymusu i gwarancji zasiłku, niż rzeczywistej potrzeby;

- wartość diagnostyczna uzyskanego materiału empirycznego ze strony uczniów czeczeńskich nie wydaje się wystarczająca dla wniosków dotyczących adaptacji szkolnej i funkcjonowania społecznego w szkole (słaba znajomość języka polskiego lub całkowity jej brak, co pozwala sądzić o słabych kompetencjach komunikacyjnych i społecznych). Niski potencjał lingwistyczny wydaje się jedną z podstawowych barier w integracji szkolnej;

- większość badanych uczniów narodowości czeczeńskiej lubi swoją 
szkołę, pozytywnie ocenia polskich nauczycieli a także swoich polskich rówieśników.

W środowisku objętej badaniami szkoły, Czeczeni nie zawsze spotykają się ze zrozumieniem i akceptacją. Status uchodźcy jest swoistym piętnem, gdzie - jak pisze Erving Goffman (2007) - w zetknięciu z obcym może wyjść na jaw, że ma on jakiś atrybut różniący go od innych członków przypisanej mu kategorii, który czyni go osobą mniej pożądaną społecznie. Obecność uchodźców z istoty stanowi kategorię społeczną, której atrybutami są: marginalizacja, odrębność tożsamości społeczno-kulturowej, wynikające stąd bariery interakcyjne, problemy natury socjalnej generujące niski status ekonomiczny i ubóstwo a tym samym dyskredytację ze strony grupy dominującej w przestrzeni społecznej. Brak potencjału lingwistycznego i niezrozumiałe przez grupę dominującą kody kulturowe oraz piętno uchodźcy, wyznaczają społeczną pozycję dzieci czeczeńskich. Ignorują one kulturę większości, kompensując szkolną marginalizację wzmacnianiem własnej tożsamości. Stan ten odpowiada klasyfikacji wyjaśnień przyczyn niepowodzeń szkolnych dzieci z mniejszości etnicznych, określanych przez Tove Skutnabb-Kangas teoriami deprywacji (Gmerek, 2014, s. 181-182).

\section{Podsumowanie}

Transmisja i reprodukcja wartości kulturowych w przypadku różnorodności habitusów pierwotnych, wynikających z odmienności narodowej i etnicznej wybranych grup w polskiej szkole cechuje złożoność przestrzeni społecznej, zdominowanej przez uczniów polskich. Dokonująca się symboliczna „przemoc" wobec mniejszości narodowej i etnicznej w szkole jest konsekwencją dominujących dyskursów kultury, w których zgodnie z zasadami stratyfikacji społecznej u Bourdieu i Bersteina powstaje system transmisji wiedzy z dominującym językiem kształcenia. Poziom jego opanowania przez wielokulturową mniejszość w edukacji szkolnej decyduje o poziomie komunikacji społecznej, a zatem określa zakresy barier interakcyjnych. Mogą one pogłębiać społeczną dyskredytację i rodzić niechęć do integracji - a nawet świadomie prowadzić do izolacji - jak to ma miejsce na przykładzie uczniów czeczeńskich i romskich w polskiej szkole. Jest to swoiste uproszczenie, gdyż problem jest znacznie bardziej złożony i wielowątkowy. Wymaga zatem interdyscyplinarnych analiz i dociekań. Transmisja wiedzy i reprodukcja wartości kulturowych mimo różnic w habitusach pierwotnych może przebiegać harmonijnie, w sytuacji wysokiej sprawności lingwistycznej i sprawnej dys- 
trybucji kultury, nie odbiegającej od grupy dominującej, z czym spotykamy się $\mathrm{w}$ pedagogicznych relacjach z uczniami wietnamskimi.

Pojawiająca się w artykule refleksja badawcza jest wąską prezentacją uzyskanego materiału empirycznego odnoszącego się do społecznej przestrzeni szkoły w warunkach wielokulturowości.

\section{Bibliografia}

Bielecka-Prus, J. 2010. Transmisja kultury w rodzinie $i$ w szkole. Teoria Basila Bernsteina. Warszawa: PWN.

Bourdieu, P. i Passeron, J. 2006. Reprodukcja. Elementy teorii systemu nauczania. Warszawa: PWN.

Denek, K. 1994. Wartości i cele w edukacji szkolnej. Poznań - Toruń: EDYTOR.

Dobrowolska, B. 2011. Sytuacja dziecka romskiego w szkole w latach 80. XX wieku i wspótcześnie. Toruń: Wydawnictwo Adam Marszałek.

Dobrowolska, B. 2015. Wspótczesna szkoła w kontekstach wielokulturowości . Wzajemna recepcja „swoich” $i$ „obcych” w praktyce szkolnej. W: Szczurek-Boruta, A. i Chojnacka-Synaszko, B. red. Szkoła - kultura - środowisko lokalne. Toruń: Wydawnictwo Adam Marszałek, ss. 42-56.

Dobrowolska, B. 2015. Postawy nauczycieli wobec edukacji międzykulturowej a kultura szkoły. Studium społeczno-pedagogiczne. Kraków: Oficyna Wydawnicza „Impuls”.

Gmerek, T. 2014. Język, edukacja i nierówności społeczne. Konteksty teoretyczne. W: Gromkowska-Melosik, A. i Szymański, M. J. red. Edukacja i nierówność. Trajektorie sukcesu i marginalizacji. Poznań: UAM, ss.163-188. Goffman, E. 2007. Piętno. Rozważania o zranionej tożsamości. Gdańsk: GWP. Halik, T. 2006. Migrancka społeczność Wietnamczyków w Polsce w świetle polityki państwa i ocen społecznych, Poznań: UAM.

Halik, T., Nowicka, E. i Połeć, W. 2006. Dziecko wietnamskie w polskiej szkole. Zmiana kulturowa i strategie przekazu kultury rodzimej w zbiorowości Wietnamczyków w Polsce. Warszawa: Prolog.

Nikitorowicz, J. 2009. Edukacja regionalna i międzykulturowa. Warszawa: WAiP.

Nowicka-Rusek, E. 2011. Szkoła, rodzina i dzieci romskie. W: Kołaczek, M. i Talewicz-Kwiatkowska, J. red. Funkcjonowanie poznawcze i jezzkowe dzieci romskich uczęszczajacych do szkót specjalnych $i$ masowych - konteksty społeczne. Oświęcim: Stowarzyszenie Romów w Polsce, ss. 35-50. 
Pozarządowa Agencja Ewaluacji i Rozwoju, Stowarzyszenie Biuro Obsługi Inicjatyw Społecznych, 2011, http://rownosc.info/media/uploads/raport-z-badania-ewaluacyjnego-programu-na-rzecz-spolecznosci-romskiej-w-polsce.pdf (17.10.2016).

Szacki, J. 2002. Historia myśli socjologicznej. Warszawa: PWN.

Szkudlarek, T. 2010. Pedagogika krytyczna. W: Kwieciński, Z. i Śliwerski, B. red. Pedagogika. Podręcznik akademicki, T. 1. Warszawa: PWN, ss. 363377.

Szlendak, T. 2010. Socjologia rodziny. Ewolucja, historia, zróżnicowanie. Warszawa: PWN.

\title{
Transmission and reproduction of cultural values at school exem- plified by selected national and ethnic minorities versus the social context. Some elements of the theories of Pierre Bourdieu and Basil Bernstein
}

\begin{abstract}
Family and school are not always compatible educational environments, even more so in the case of cultural differences resulting from various national and ethnic status. There is a need for conducting multidisciplinary analyses regarding transmission and reproduction of cultural values and the role of school in accounting for said differences in school practice.

School is facing special tasks of a regulatory, axiological, and adaptive nature serving both the integration of culturally diverse environments and cultural potential of minorities. The overview of dissimilarity of habitus of three selected minority and ethnic groups (Vietnamese, Chechen, and Romani) in the presented study is preceded by theoretical considerations including elements of Bordieu's and Bernstein's theories. Each theory underlines issues regarding social stratification which, due to differences in habitus, levels of linguistic competence and the symbolic "violence" of culture of the majority, raises questions about educational opportunities and social integration of minorities within the school space. In addition to examples of good social integration (Vietnamese students), we also find school to be a place of interactional barriers (Chechen students) and a space where students consciously chose to isolate themselves in order to protect their own identity (the Romani).
\end{abstract}

Keywords: transmission, reproduction, school, minority, ethnic groups 